\title{
Treatment of Traditional Cloth Wastewater by Electrocoagulation Using Aluminum Electrodes
}

\author{
Rusdianasari $^{1}$, Yohandri Bow ${ }^{1}$, Yuniar ${ }^{1}$ \\ ${ }^{1}$ Chemical Engineering Department, State Polytechnic of Sriwijaya, Palembang 30139, Indonesia \\ E-mail: rusdianasari19@gmail.com,andre_bow@yahoo.com,yuniar@polsri.ac.id
}

\begin{abstract}
The existence of the textile industry in Indonesia is not only included in the category of large and medium scale industries, but also in small-scale and some even in the household (home industry). This led to the pollution caused by the textile industry, especially as a result of the presence of the textile dyeing not only occur in industrial areas but also occurs in densely populated settlements. To overcome the problem of environmental pollution that occurs, it needs treatment of the textile wastewater. Treatment of traditional cloth wastewater by electrocoagulation using aluminum electrode material has been investigated in this paper. The effect of relevant wastewater characteristics such as $\mathrm{pH}$ and conductivity, and important process variables such as applied voltage and operating time on the chemical oxygen demand (COD), biological oxygen demand (BOD), turbidity, total suspended solid (TSS) and total dissolved solid (TDS). The processing time is used $60,75,90,105,120$ minutes and for the variation of the applied voltage is $6 \mathrm{~V}, 12 \mathrm{~V}, 18 \mathrm{~V}$, and $24 \mathrm{~V}$. The best conditions and the effectiveness of electrocoagulation for each parameter varies with the voltage is in the range between $6 \mathrm{~V}-18 \mathrm{~V}$ with the processing time between 90-120 minutes. The effectiveness of electrocoagulation method to decrease the turbidity value 99.634\%; TSS 49.679\%; TDS $17.243 \%$; BOD 91.778\%; COD 97.260\% and to decrease the conductivity value of $23.631 \%$ and the increase in pH from 6.34 to 7.79 .
\end{abstract}

Keywords — traditional cloth wastewater; electrocoagulation; aluminum electrodes

\section{INTRODUCTION}

Wastewater from dyeing and finishing processes, with a chemical oxygen demand (COD) concentration exceeding quality standard and a strong dark color, is categorized as high strength wastewater [1-3]. It is a significant source of environmental pollution.

The combination of strong color and highly suspended solid content results in high turbidity of the waste effluent. Due to the characteristic of textile waste water, COD and turbidity removals exhibit similar trends.

Conventional method for dealing with textile wastewater consist of various combination of biological, chemical and physical method $[4,5]$. Because of the large variability of the composition of textile wastewater, most of these conventional methods are becoming inadequate and insufficient. Furthermore, treatment cost of textile waste effluent has been escalating fairly rapidly in recent years. On the hand, due to the scarcity of space, extremely high land cost and the complexity of handling chemicals in some countries, a simple and efficient treatment process for the textile wastewater is essentially necessary. It should require minimum chemical consumption and space.

One of promising methods for treating hard-to-treat wastewater streams is the electro-chemically based. Electrochemical processes (electrolysis and electrocoagulation) have been successfully demonstrated for removing pollution in various industrial wastewaters $[6,8]$. Removal mechanisms reported in the electrolysis process generally include oxidation, reduction, decomposition, whereas the mechanisms in the electrocoagulation process include coagulation, adsorption, precipitation and flotation [9-11]. Electrocoagulation utilizes aluminum anodes to produce aluminum hydroxide flocs by reaction at the anodes followed by hydrolysis.

The electrocoagulation is a simple and efficient methods for the treatment of many water and wastewaters. It has not been widely accepted because of high initial capital costs as compared to others treatment technologies. In recent years, many investigations have been especially focused on the use of electrocoagulation owing to the increase in environmental restriction on effluent wastewater [12-14]. Electrocoagulation has been applied successfully to treat 
potable water [15], food and protein wastewater, yeast wastewater, urban wastewater, restaurant wastewater, tar sand and oil shale wastewater, nitrate containing wastewater solutions [21] and coal stockpile wastewater [17-19]. Electrocoagulation has been proposed in recent years as an effective method to treat wastewater streams from dyeing factories. The electrogenerated flocs separate rapidly and remove color and turbidity from dyeing wastewaters [20-21]. Electrocoagulation treatments of textile dye-containing solutions or wastewater samples have been conducted on a laboratory scale and good removal of COD, color, turbidity and dissolved solids at varying operating conditions have been obtained. Electrocoagulation has been explored in combination with the addition of polymer solution. The process has been found to be very efficient in COD removal and decoloration with low-energy consumption [19].

\section{EXPERIMENTAL}

Wastewater was obtained from a tank containing a mixture of exhaust dyeing solutions at a traditional cloth industry in Palembang (Indonesia). The wastewater was first filtered using a screen filter to remove large suspended solid before it was used for the subsequent studies.

The experimental setup is shown in Fig. 1. The thermostated electrocoagulator was made of plexyglas with the dimension $60 \mathrm{~mm} \times 60 \mathrm{~mm} \times 100 \mathrm{~mm}$ at constant stirring speed $(200 \mathrm{rpm})$. There are two monopolar electrodes (anode and cathode) of the same dimensions. Aluminum electrodes made from plates with dimensions of $50 \mathrm{~mm} \times 75 \mathrm{~mm} \times 10$ $\mathrm{mm}$. The total effective electrode connected was $85 \mathrm{~cm}^{2}$ and the spacing between electrodes was $10 \mathrm{~mm}$. The electrodes were connected to a digital DC power supply with potentiostatic or galvanostatic operational options.

All the runs were performed at constant temperature of 25 ${ }^{\circ} \mathrm{C}$. In each run, $300 \mathrm{~cm}^{3}$ of the wastewater solutions were placed into the electrolytic cell. The potential was adjusted to a desired value and the coagulation was started. At the end of electrocoagulation, the solution was filtered and the impurities on the aluminium electrode surfaces were remove by dipping for $5 \mathrm{~min}$ in a solution freshly prepared by mixing $100 \mathrm{~cm}^{3} \mathrm{HCl}$ solution $(35 \%)$ and $200 \mathrm{~cm}^{3}$ of hexamethylenetetramine aqueous solution $(2.80 \%)$ [22]. At the end of the run, the electrodes were washed thoroughly with water to remove any solid residues on the surface, dried and re-weighted.

COD, TSS, and turbidity were carried out according to the Standard Methods for Examination of Water and Wastewater [30]. The $\mathrm{pH}$ was measurement by a $\mathrm{pH}$ meter, conductivity was determined by a conductivity meter. The $\mathrm{pH}$ and conductivity were adjust to a desirable value using $\mathrm{NaOH}$ or $\mathrm{H}_{2} \mathrm{SO}_{4}$, and $\mathrm{NaCl}$ (Merck) respectively.

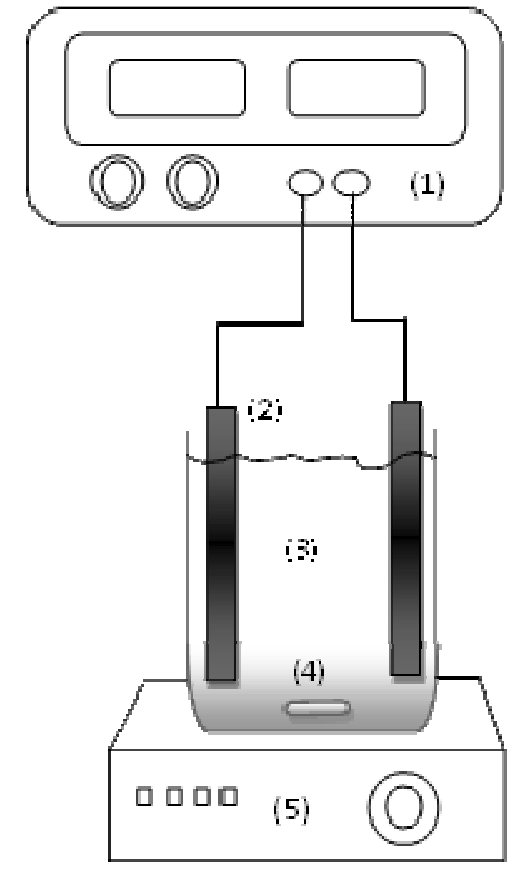

1. DC Power Supply

2. Aluminum Electrodes

3. Traditional cloth wastewater

4. Magnetic stirrer

Fig.1 Schematic diagram of experimental setup

\section{RESULT AND DISCUSSION}

Based on preliminary experimental results, the processing time was used $60,75,90,105,120 \mathrm{~min}$ and for the variation of applied voltage (potential) was 6, 12, 18, and $24 \mathrm{~V}$.

\section{A. Effect of time process and potential on the TDS value}

TDS impairment on highly effective electrocoagulation which will produce an effluent with a TDS content of less. Impairment occurs when the TDS can be compressed double layer (double layer) that occur around the charged species due to interactions with ions formed by oxidation at the electrode. The presence of these ions cause a reduction in repulsion between the particles in the wastewater so that the coagulation process can take place.

In Fig. 2 it can be seen that the best TDS impairment is at a potential of $12 \mathrm{~V}$ where the value of TDS in the state declined slowly with the variation of the contact time with the smallest value of $2.846 \mathrm{ppm}$ TDS at the time of 120 minutes, all with slightly different TDS value at a potential of $18 \mathrm{~V}$ the process time of $120 \mathrm{~min}$ is $2.848 \mathrm{mg} / \mathrm{L}$. 


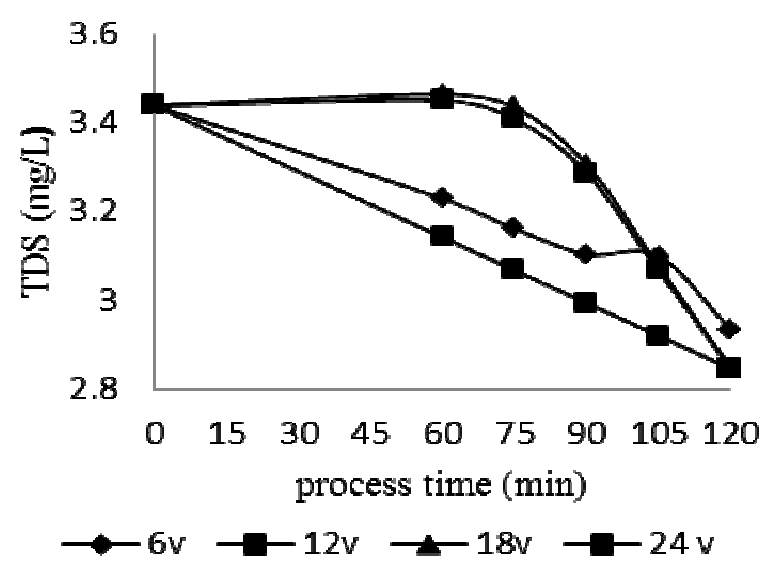

Fig. 2 Effect of time process and potential on the TDS value

\section{B. Effect of time process and potential on conductivity}

From the analysis of the conductivity of traditional cloth wastewater with the data obtained in Fig. 3. Decrease the best conductivity value that is contained in the process time of 120 minutes with a potential of $12 \mathrm{~V}$ where the value of conductivity in the state fell by $2,818 \mu \mathrm{S} / \mathrm{cm}$ from the initial conductivity value of $3,69 \mu \mathrm{S} / \mathrm{cm}$. Conductivity value at a potential of $12 \mathrm{~V}$ look down with a stable unlike other potential variation are visible up and down.

Conductivity is a measure of the ability of a material to conduct electric current associated with the concentration of ionized in solution. The decline in the value of conductivity in the electrocoagulation process may occur due to the different distribution of ion composition causing different conductivity values, as indicated conductivity of dissolved ions in the water sample. Each ion has a value different conductivity. The higher the number the turbidity of the sample, in this case associated with the content of dissolved solids in the sample, the higher the conductivity value.

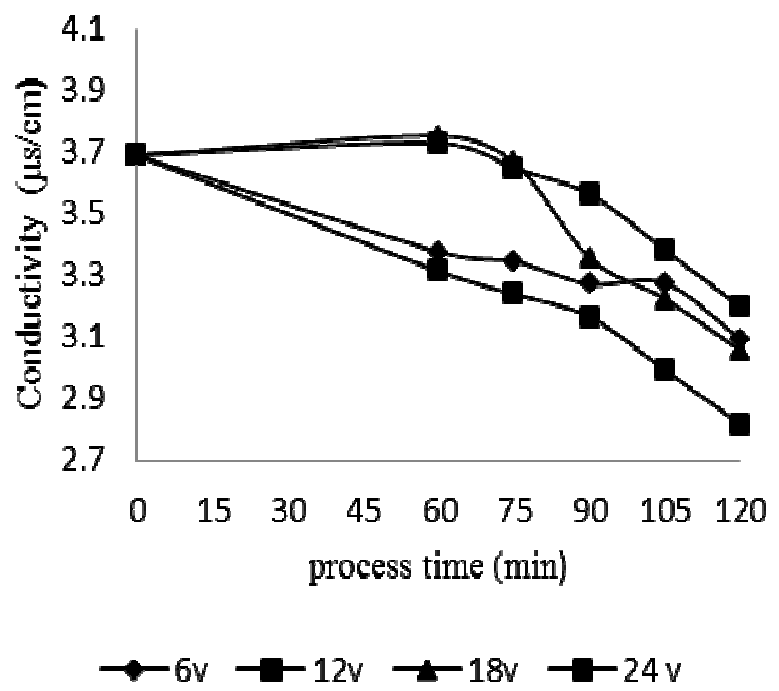

Fig. 3 Effect of time process and potential on conductivity

\section{Effect of time process and potential on turbidity}

Turbidity at a wastewater caused by the presence of a mixed object or objects in the water colloid. Turbidity is closely related to levels of suspended substances because of the turbidity of the water is caused by suspended substances in the water. Suspended substances in the water that is composed of various substances, such as fine sand, clay, and natural sludge which is inorganic materials or can be in the form of organic material floating in the water. This makes a real difference in terms of aesthetics and in terms of the quality of the water itself.

In Fig. 4 it can be seen turbidity impairment occurs very rapidly at any potential variations. The longer the processing time and the greater the potential used, the turbidity will be smaller. In this experiment electrocoagulation best results for the turbidity value at the time of 90 min with a potential of $12 \mathrm{~V}$, where the value dropped from 30.8 NTU turbidity to $0.11 \mathrm{NTU}$

Turbidity impairment in the electrocoagulation may occur due to the presence of fine bubbles of hydrogen gas that tends to break away from the electrode. The gases coming out of the liquid waste is then bind colloidal particles that are suspended in the wastewater and then float to the surface as foam waste. A growing number of colloidal particles suspended in the waste, the more foam is formed.

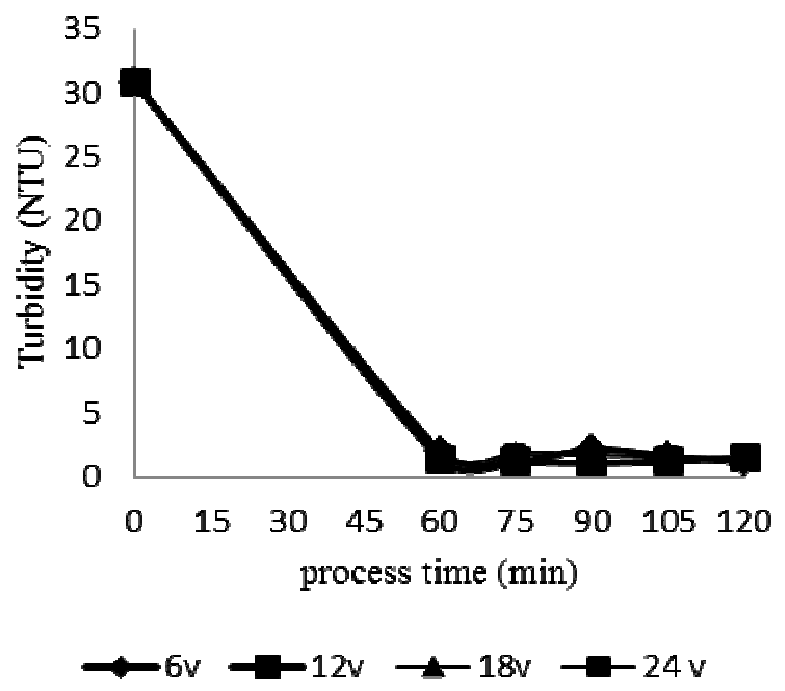

Fig. 4 Effect of time process and potential on turbidity

\section{Effect of time process and potential on TSS}

From Fig. 5 it can be seen from the results traditional cloth wastewater by electrocoagulation method that has been carried. The best results in a decrease in the TSS value at the process time of $120 \mathrm{~min}$ with a potential of $6 \mathrm{~V}$ where it dropped to $9.2 \mathrm{mg} / \mathrm{L}$. TSS reduction process is very influential where TSS are pollutants that are in suspension. If a wastewater containing high TSS it can be concluded that 
the waste of poor quality and potentially damaging aquatic ecosystems in particular.

TSS reduction in the electrocoagulation process occurs when the solid material of the suspended solids in the coagulant adsorbed onto $\mathrm{Al}(\mathrm{OH})_{3}$ or adsorbed onto the air bubbles. The results of this adsorption will be integral to the top (floating) resulting in a decrease in the concentration of TSS in wastewater.

TSS pollutant sources are materials both organic and inorganic chemicals that make up the suspension in the wastewater. In addition, the source of TSS is also derived from the metals that form complex compounds either with hydroxide or other anions of these compounds suspended in the waste solution either because of the nature of the compound molecule size and polarity properties owned.

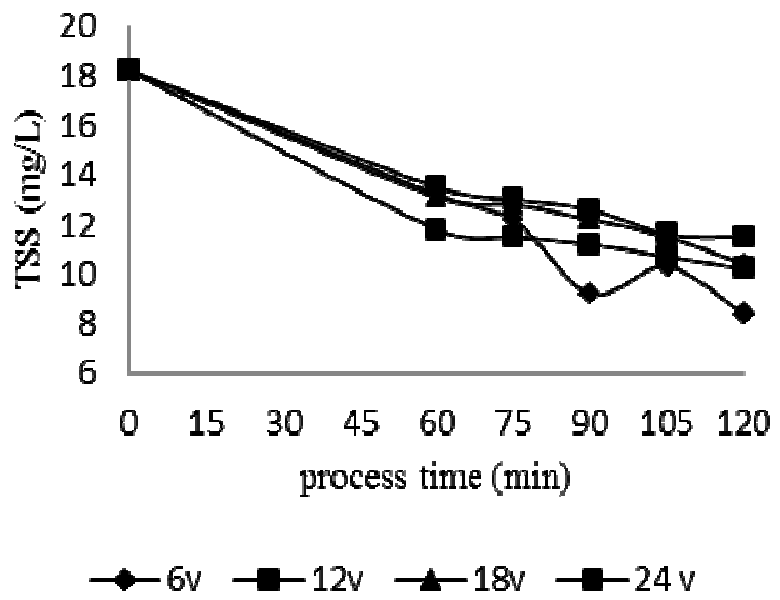

Fig. 5 Effect of time process and potential on TSS

\section{E. Effect of time process and potential on BOD value}

In Fig. 6, the results of electrocoagulation traditional cloth wastewater, the BOD value is decreasing. From the graph it can be seen the best results to the reduction of BOD value is at the time of 60 minutes and a potential $18 \mathrm{~V}$ with a BOD value of $1.85 \mathrm{mg} / \mathrm{L}$. At the time the process occurs in a significant change in the BOD value of $22.5 \mathrm{mg} / \mathrm{L}$ to 1.85 $\mathrm{mg} / \mathrm{L}$, but the longer the process time at a potential $18 \mathrm{~V}$, the BOD values will rise slowly even though the changes are not too large, it this occurs because the larger the applied voltage and the longer time the electrode process used will be saturated so that the electrocoagulation process reached its lowest point and the resulting increase in the value of BOD. Steady decline in BOD values can be seen in Fig. 6, which occurs at a potential of $6 \mathrm{~V}$ and $12 \mathrm{~V}$.

The results of this BOD analysis determines the quality of water bodies that are much needed oxygen for the organisms destroy organic matter at a particular time. High BOD values play an important role in determining the ability of a body of water to support the growth of algae and aquatic organisms that will result in increased growth. The higher amount of bacteria population, the higher the level of the water pollution.
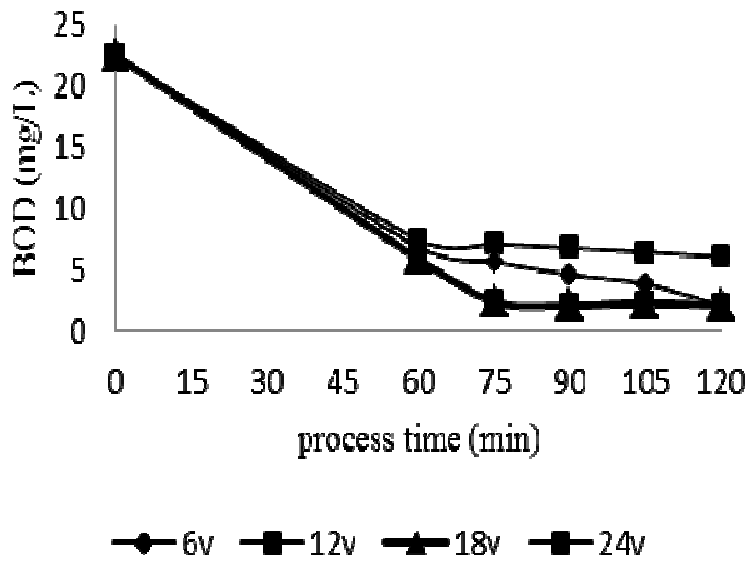

Fig. 6 Effect of time process and potential on BOD value

\section{F. Effect of time process and potential on COD value}

COD is the quantity or amount of oxidant that reacts with the sample under certain conditions. The number of unused oxidant that is proportional to the oxygen demand. Organic and inorganic compounds in the sample is oxidized subjects but more dominant organic compounds. COD is often used as a measure of the quantity of pollutants in the wastewater.

In Fig. 7 the results of the study traditional cloth wastewater using electrocoagulation method can be seen best results in a decrease in the COD value at the time of $60 \mathrm{~min}$ with a potential of $18 \mathrm{~V}$ where the reduction in COD values at the very drastic conditions, namely from $73 \mathrm{mg} / \mathrm{L}$ to 2 $\mathrm{mg} / \mathrm{L}$, although the longer the processing time used its value will increase, this is because the electrodes that have been used already saturated.

COD impairment test on this electrocoagulation occurs through destabilization. Performed by the destabilization of colloidal metal cations form complexes polyvalen poly hydroxide. This complex compound has a high adsorption side thus simplifying the process of merging (aggregation) with a variety of pollutants that make up the large material which is separated by flotation technique for density/material density becomes smaller.

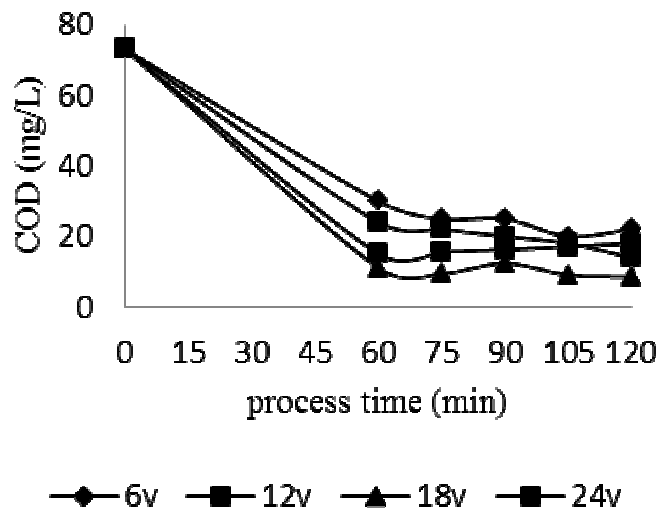

Fig. 7 Effect of time process and potential on COD value 


\section{G. Effectiveness electrocoagulation method in traditional cloth wastewater}

The effectiveness of the method in treating traditional cloth wastewater by electrocoagulation method parameters decreased levels of TDS, conductivity, turbidity, TSS, BOD, and COD value and increase the $\mathrm{pH}$ value in the experiment varied. Efficiency of a good potential electrical is between 6 $\mathrm{V}-18 \mathrm{~V}$ with a different process. For TSS impairment potential that is best used with a $6 \mathrm{~V}$ processing time of 120 min. To decrease the value of TDS, and conductivity are best used potential is $12 \mathrm{~V}$ with a processing time of $120 \mathrm{~min}$. TDS, conductivity and turbidity with time for the 90 minutes, whereas for BOD and COD values decrease with potential is $18 \mathrm{~V}$ and processing time of $60 \mathrm{~min}$. To increase the $\mathrm{pH}$ value of the good is the potential of $6 \mathrm{~V}$ with a processing time of $105 \mathrm{~min}$. In Fig. 7 showed electrocoagulation effectiveness on potential $12 \mathrm{~V}$.

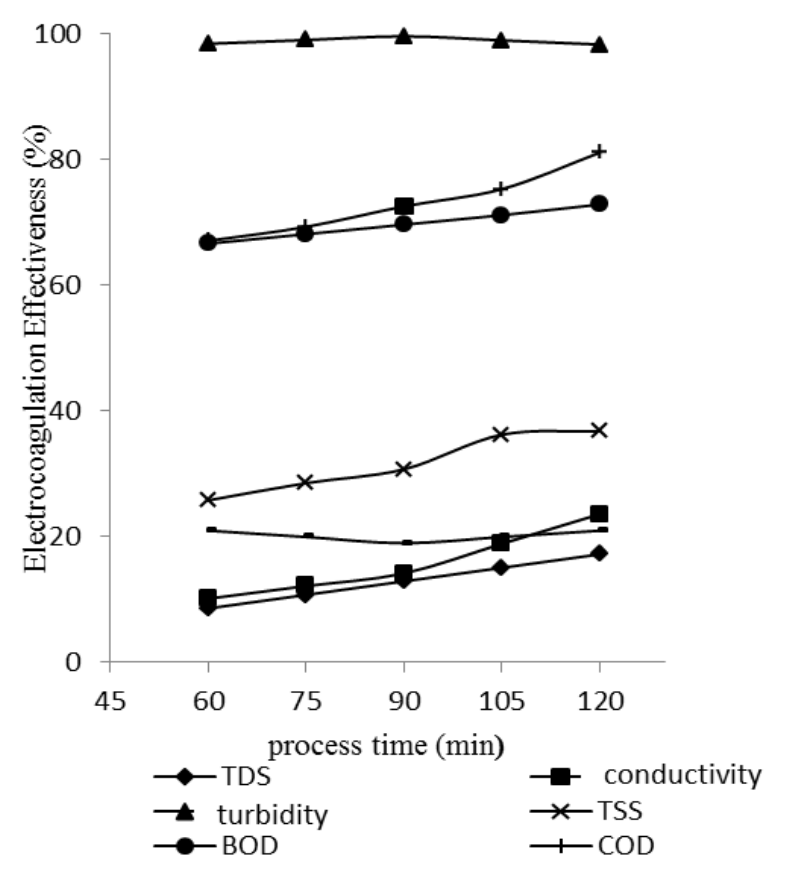

Fig. 7 Effectiveness electrocoagulation method in traditional cloth wastewater

\section{CONCLUSIONS}

Considering the results obtained from the experiment of traditional cloth wastewater by electrocoagulation methods, the following outcomes can be achieved:

- Electrocoagulation, in comparison with other water treatment facilities is cheaper and more efficient in dye elimination of solutions containing dye eliminator

- Electrocoagulation does not need much chemicals

- Dye elimination rate depends on factors such as electrical potential, process time, solution primary $\mathrm{pH}$, experimented solution conductivity, time connection, distance between electrodes, solution temperature, stiring, type of electrodes and their formation.

\section{ACKNOWLEDGMENT}

We would express their sincere thanks to State Polytechnic of Sriwijaya and the traditional cloth industries that have supported this work.

\section{REFERENCES}

[1] S.H. Lin, M.L. Chen, "Treatment of textile wastewater by electrochemical methods for reuse", Water Res. 31, pp 868-876, 1997.

[2] S.H. Lin, C.F. Peng, "Treatment of textile wastewater by electrochemical methods", Water Res. 29, pp. 277-282, 1994.

[3] S.H. Lin, C.H. Lin, " Treatment of textile by ozonation and chemical coagulation”, Water Res. 27, pp. 1743-1748, 1993.

[4] G.F. Babuna, B. Soyhan, G. Eremektar, D. Orhon, "Evaluation of treatability for two textile mill effluents", Water Sci. Technol. 40, pp. 145-152, 1999.

[5] Y.M. Slokar, A.M.L. Marechal, "Methods of decoloration of textile wastewaters", Dye Pigments 37, pp. 335-356, 1998.

[6] A.G. Vlyssides, P.K. Karlis, M. Loizidoy, A. Zorpas, D. Arapoglou, "Treatment of leachate from a domestic solid waste sanitary landfill by an electrolysis system", Environ. Technol. 22, pp. 1467-1476, 2001.

[7] C.T. Tsai, S.T. Lin, Y.C. Shue, P.I. Su, "Electrolysis of soluble organic matter in leachate from landfills", Water Res. 31, pp. 30733081, 1997

[8] J. Naumczyk, L. Szpyrkowicz, D.M. De Faverri, F. Zilio-Grandi, "Electrochemical treatment of tannery wastewater containing high strength pollutants", Trans. IChemE 74B, pp. 59-68, 1996.

[9] A.G. Vlyssides, P.K. Karlis, A.A. Zorpas, "Electrochemical oxidation of noncyanide strippers waters", Environ. Int. 25, pp. 663670, 1999.

[10] J. Grimn, D. Bessarabov, R. Sanderson, "Review of electro-assited methods for water purification", Desalination 115, pp. 285-294, 1998.

[11] K. Rajeshwar, J.G. Ibanez, G.M. Swai, "Electrochemistry and the environment", J. Appl. Electrochem. 24, pp. 1077-1091, 1994.

[12] M.Y.A.Mollah, R. Schennach, J.P. Parga, D.L. Cocke, "Electrocoagulation (EC)-science and application", J. Hazard. Mate. B84, pp. 29-41, 2001.

[13] X. Chen, G. Chen, P.L, Yue, "Separation of pollutants from restaurant wastewater by electrocoagulation", Sep. Purif. Technol. 19 , pp. 65-76, 2000

[14] S.H. Lin, C.T. Shyu, M.C Sun, "Saline wastewater treatment by electrochemical method", Water Res. 32, pp. 1059-1066, 1998.

[15] M.J. Matteson, R.L. Dobson, R.W. Glenn Jr., N.S. Kukunoor, W.H. Waits III, E.J. Calyfield, "Electrocoagulation and separation of aqueous suspensions of ultrafine particles", Coll. Surf. A: Physicochem. Ang. Aspect 104, pp. 101-109, 1995.

[16] M. Kobya, O.T. Can, M. Bayramoglu, "Treatment of textile wastewaters by electrocoagulation using iron and aluminum electrodes", J. Hazard. Mat. B100, pp. 163-178, 2003.

[17] Rusdianasari, S. Arita, E. Ibrahim, Ngudiantoro, "Reduction of metal contents in coal stockpile wastewater using electrocoagulation", Applied Mech. and Materials, Vol. 391, pp. 29-33, 2013.

[18] Rusdianasari, S. Arita, E. Ibrahim, Ngudiantoro, "Application of electrocoagulation process for coal stockpile wastewater treatment", in Proc. Int. Conf. Chem. Eng. On Sci. and Appl., 2013.

[19] Rusdianasari, S. Arita, E. Ibrahim, Ngudiantoro, "Treatment of coal stockpile wastewater by electrocoagulation using aluminum electrodes", J. Adv. Material Sci., Vol. 896, pp. 145-148.

[20] T. Picard, G. Cathalifaund-Feuillade, M. Mazet, C. Vandensteendam, "Cathodic dissolution in the electrocoagulation process using aluminum electrodes", J. Environ. Monit. 2, pp. 77-80, 2000.

[21] A. Gurses, M. Yalcin, C. Dogan, "Electrocoagulation of some reactive dyes: a statistical investigation of some electrochemical variables", Waste manage. 22, pp. 491-499, 2002.

[22] J.S.Do, M.L. Chen, "Decolorization of dye-containing solution by electrocoagulation", J. Appl. Electrochem. 24. pp. 785-790, 1994. 